\title{
MUSIK KONTEMPORER
}

\section{Oleh : Yohan C. Tinungki, S.Mus, M.Sn}

\section{Kontemporer}

Banyak pertanyaan diajukan berkenaan dengan istilah kontemporer. Pada tahun 1980-an, istilah kontemporer menjadi polemik dan telah cukup banyak menimbulkan kesalahpahaman; sementara di Amerika dan Eropa sendiri (asal istilah kontemporer) sudah tidak dipersoalkan lagi sejak lama. Kata kontemporer sendiri berasal dari kata Cum dan Tempus; cum berarti bersamaan, dan tempus berarti waktu. Jadi, kontemporer dapat diartikan bersamaan waktu atau sezaman.

Sesungguhnya, istilah kontemporer itu umum sifatnya; ia tidak menunjuk pada sesuatu apapun yang bersifat spesifik, kecuali menyiratkan tentang suatu waktu "masa kini", atau sesuatu yang bersifat "kekinian", yang tidak dibatasi oleh suatu periode waktu tertentu. Artinya, setiap seni pada saatnya pernah dan akan menjadi kontemporer. Sebagai contoh, musik kontemporer hanya dapat dipahami dalam hubunganya dengan perkembangan sejarah musik Barat di Eropa dan Amerika. Namun, walaupun dapat mengacu pada sebuah pemahaman yang spesifik, sesungguhnya label kontemporer yang dibubuhkan pada kata seni maupun musik sama sekali tidak menunjukkan pada sebuah pengertian yang per definisi bersifat normatif. Itulah sebabnya, terutama bagi yang awam, seni atau musik kontemporer banyak menimbulkan kesalahpahaman yang berlarut-larut.

Era kontemporer (musik) sudah dimulai sejak lama melalui suatu perjalanan panjang yang diawali oleh komponis pelopornya yaitu Bartok, Stravinsky, dan Schoenberg.. Ruang-ruang lama abad tonal dan tonika tunggal klasik-romantik telah disekat untuk memberi ruang baru yang lebih terbuka yaitu musik moderen abad 20.

Kontemporer dalam arti sezaman menjelaskan bahwa jika saya kontemporer (sezaman) dengan Bach, maka saya akan mengangkat satu karya Bach yang akan saya garap dengan gaya moderen kontemporer saat ini; artinya, saya akan membawa nuansa Barok abad ke-16 ke nuansa moderen abad ke-20. Bahkan ketika tipe musik yang lebih tua muncul kembali menjadi puncak gelombang, ia muncul dengan hiasan-hiasan yang tidak dikenal oleh generasi penciptanya; jadi, apabila klasisme timbul kembali sebagai suatu reaksi terhadap kontemporisme ekstrem tahun 60an pada abad ini, ia bukanlah klasisme Bach atau Mozart, melainkan klasisme baru dari suatu era yang baru. Orang boleh menerapkan kata 
kontemporer dengan Bach, tetapi hal itu berarti pembicaraan yang muncul hanya terbatas pada peristiwa-peristiwa pada zaman Bach.

Sifat-sifat dasar kontemporer pada setiap zaman, dulu maupun kini tidak pernah berubah, yaitu menyangkut kebutuhan akan adanya pembaruan sebagai tuntutan terhadap masa lalu yang dianggap sudah tidak relevan dan usang. Tuntutan akan pembaruan ini kita sebut sebagai "transformasi sebuah zaman" yang pada gilirannya akan selalu menimbulkan 3 faktor goncangan besar yaitu:

1. Kehendak umum akan adanya perubahan, perombakan (reformasi) sampai revolusi.

2. Sebagai akibat logisnya, terjadi distrosi sejarah (dengan masa lalu).

3. Timbulnya sifat kesementaraan pada "transformasi zaman".

\section{Musik Kontemporer}

Jika berbicara tentang musik kontemporer, apakah sama dengan estetika yang berbicara tentang "keindahan?"

Musik, betapapun hebatnya ia dibuat, akan tetap hanya menjadi sekedar fenomena bunyi belaka apabila ia tidak berkenan dan tidak mendapat tanggapan dalam kesadaran diri manusia. Pada dasarnya, musik dalam jenis dan bentuk apapun kini tidak memerlukan lagi alat penerjemah karena ia langsung akan menjelaskan dirinya sendiri

Pada tahun 1900-an, sejarah mencatat adanya pengaruh-pengaruh baru atas beberapa unsur musikal yang diterapkan dalam musik kontemporer, pengaruh-pengaruh baru itu adalah:

1. Struktur Ritmis atas Melodis

a. Perubahan motif-motif simetris

b. Perubahan sukat (birama)

2. Kesatuan Intervalik

a. Perubahan ritmis (alterasi ritmis)

b. Perubahan melodis (alterasi melodis)

c. Penerapan kontraksi (pengerutan) motif

3. Pertumbuhan Harmonik

a. Ekspansi kromatis dari tonalitas

b. Akor-akor Appoggiatura

4. Rincian akor 9

a. Tempatnya dalam overtone series 

b. Akor 9 dominan dalam skala mayor dan minor
c. Penyuaraan
d. Invensi
e. Progresi

5. Akor 11 dan 13
a. Akor 11 natural
b. Akor ll Augmented
c. Invensi
d. Akor 13

6. Akor Leading-Tone
a. Reevaluasi terhadap bas berfigur
b. Akor 11 Half-dim
c. Akor Augmented sixth

Memasuki zaman Impresionisme, terjadi beberapa perubahan pokok, yaitu:

1. Pengaruh Modal

2. Pengaruh Modal atas Harmoni

a. Hilangnya Leading-Tone

b. Progresi Root (progresi dasar)

c. Tonalitas

3. Muncul juga sistem Pararelisme: suatu gerak melodis yang tidak terikat dalam semua anggota akor

4. Tritonus, skala whole-tone, dominan whole-tone

Kemudian muncullah disonansi moderen yang meliputi:

1. Kontrapung bebas dan skala 12 nada

2. Teknik trinada independen

3. Penulisan bikordal (dua akor/akor ganda), tonalitas ganda (politonalitas), dan infleksi ganda. Yang akhirnya dijumpai sebuah warisan berupa Atonalitas.

Satu hal yang perlu kita pahami adalah: musik kontemporer tidak selalu musik yang baru, dan musik baru tidak selalu kontemporer. Terdapat dua gelombang yang saling bertentangan yaitu gelombang pembaruan (inovasi), dan gelombang penyederhanaan (simplifikasi). Apabila gelombang inovasi lebih tinggi, seni pada saat tersebut menjadi seni yang baru; apabila gelombang retrogresi (gerak mundur) muncul, seni tersebut merunut-balik langkah-langkah sejarahnya. Tetapi, bahkan ketika 
tipe musik yang lebih tua muncul kembali menjadi puncak gelombang, ia muncul dengan hiasan-hiasan yang tidak dikenal oleh generasi penciptanya; jadi, apabila klasisme timbul kembali sebagai suatu reaksi terhadap kontemporisme ekstrem tahun 60-an pada abad ini, ia bukanlah klasisme Bach atau Mozart, melainkan klasisme baru dari suatu era yang baru.

Musik kontemporer utamanya adalah rangsangan (sensualitas), bukan rasa; karena semboyan aktualitas, musik harus mampu menggegarkan seisi kalbu, bukan hanya mengiba hati. Ia merangsang jasad, bukan menyentuh jiwa. Ini adalah batas-batas dikotomi di dalam percampuran berkesenian. Dalam musik kontemporer semua boleh, semua sah, dan semua bisa. Memang di dalam tawuran budaya kontemporer yang semua secara 'demokratis' dan merdeka-serba boleh, serba bisa, serba tidak terbatas, dan tidak lagi 'harus' begini atau begitu; sesungguhnya musik telah mati dalam pengertian Platonis yang sesungguh-sungguhnya. Semua bisa karena musik seni telah mati tertelan hiruk-piriknya suara sumbang multi media dan budaya tumpang tindih.

Mengapa kasus di atas bisa terjadi? Saat ini banyak orang yang menyebut dirinya sebagai seorang komposer dan mencoba untuk mencari identitas diri dengan beralih pada musik kontemporer, tetapi ibarat sebuah gedung dengan inisial tower yang tidak mempunyai fondasi yang kuat untuk menopang gedung tersebut, mereka juga demikian halnya, tanpa mengetahui prinsip-prinsip dalam musik kontemporer seperti yang telah disebutkan di atas, mereka telah masuk ke dalam musik kontemporer; hal ini merupakan kompensasi akibat tidak menguasai ilmu komposisi musik konvensional yang adalah landasan menuju komposisi musik kontemporer. Akibatnya, banyak pemusik maupun komposer yang melihat musik kontemporer sebagai musik yang tidak mempunyai daya estetis, serta melihatnya dengan mata tertutup. Tetapi apabila seorang komposer membuat musik konbtemporer dengan teori-teori dan prinsip-prinsip kontemporer, mungkin akan lain persepsi yang dilontarkan. Jadi, apakah estetika menjadi bagian dari musik kontemporer, dan apakah musik kontemporer masih mengandung nilai-nilai estetis? Mungkin kembali ke teori bahwa karya musik akan hidup apabila karya musik itu dapat dinikmati oleh yang membuat dan yang mendengarkannya.

Musik tidak cukup diterangkan hanya melalui emosi. Kenyataan demikian membuat musik tidak begitu saja dapat kita tangkap keberadaanya. Universalitas estetis berarti bahwa predikat keindahan tidak dibatasi pada individu tertentu, melainkan diperluas hingga mencakup seluruh bidang lingkup dari subjek-subjek yang ikut 
menimbang-nimbang perbedaan antara seni objektif dan seni subjektif; seni representasi dengan seni ekspresi sulit dipertahankan.

Yang menjadi perdebatan ialah apakah musik kontemporer mampu menggambarkan subjeknya secara harafiah, dan apakah musik kontemporer bisa dikatakan sebagai musik yang mengandung nilai estetis? Jika kita berkaca pada berkembangan dunia musik saat ini, maka yang menjadi trend dikalangan komposer ialah bagaimana membuat karya musik yang "makin aneh terdengar, maka makin enak didengar"? Jadi, di mana tempat untuk "Harmonia" (pendengaran musik: baca indah)?

Tetapi yang harus diketahui bahwa para komposer membuat musik kontemporer dengan tujuan agar bisa diterima pada zaman ini, musik mereka tidak boleh mencerminkan musik Beethoven, tetapi harus mencerminkan zaman ini. Para pendengar musik juga harus akrab dengan perbedaan-perbedaan mendasar antara musik masa lalu dengan musik masa kini. Mereka harus belajar mendengar musik Atonal atau Politonal, dan secara mendasar mampu membedakannya dengan karya-karya komposer masa lalu. Adalah penting untuk diingat bahwa musik masa kini adalah musik kita, ditulis untuk zaman yang sedang berlangsung; oleh karenanya musik kita itu harus bisa mencerminkan tentang apa yang sedang terjadi pada diri kita. Adalah suatu pengingkaran yang tidak jujur dan keliru apabila musik kita gagal mencerminkan tentang apa yang sedang terjadi.

Tulisan di atas menunjukkan betapa musik berubah dan tidak sama dari tempat ke tempat, dari waktu ke waktu, pada lingkungan yang berubah. Perubahan-perubahan itu pada toleransinya yang berbeda, baik secara kelompok maupun individu, dipengaruhi oleh kesadaran estetik dalam ruang budaya masing-masing. Baik secara instinktif, natural, maupun secara konsepsional; seperti tercermin pada substansi tulisan di atas, perubahan-perubahan itu nyata apabila kita amati dengan seksama pada musik tradisional dan musik urban masa kini. Tetapi sebaliknya, kenyataan serius yang sedang kita hadapi dalam persoalan musik masa kini adalah juga semakin sering dinegasikannya masalah estetika dalam kesadaran ruang budaya. Apakah keindahan dan ikon-ikon budaya sebagai tanda pribadi sedang ajal, Barangkali inilah persoalan paling kontemporer dalam musik kontemporer kita: perubahan tanpa konsepsi!

\section{DAFTAR BACAAN}

Berendt, Joachim. (1975), The Jazz Book, Lowrence Hill \& Company, Wetport. 
Cope, David, H. (1989), New Direction of Music, W.M.C. Brown Publishers Dubuque, lowa.

Harjana, Suka. (2003), Musik Kontemporer Dulu dan Kini, MSPI, Jakarta.

Kennedy, Michael. (2001), The Oxford Dictionary of Music, Oxford University, New York.

Langer, Suzane. (1988), Problem of Art, diterjemahkan oleh FX. Widaryanto dengan judul Problematika Seni, STSI, Bandung.

Mack, Dieter. (2004), Musik Kontemporer dan Persoalan Interkultural, Artiline, Bandung.

Persichetti, Vincent. (1961), Twentieth Century Harmony, W.W.Norton $\&$ Company, Inc, New York.

Ulehla, Ludmila. (1966), Contemporary Harmony, The Free Press, New York.

Tinungki, Yohan, C. (1992), Kantata Kontemporer, Skripsi bidang Teori dan Komposisi Musik Institut Seni Indonesia Yogyakarta.

Tinungki, Yohan, C. (2007), Kantata Nusa Lawo, Tesis bidang Komposisi Musik Barat Program Pascasarjana Institut Seni Indonesia Yogyakarta.

Gloria Cyber Ministries, Diakses 14 Mei 2008. 